\title{
Suicidal Behaviour in Bangladesh: A Scoping Literature Review and a Proposed Public Health Prevention Model
}

\author{
Afroze Shahnaz, Christopher Bagley*, Padam Simkhada, Sadia Kadri \\ Public Health Institute, Liverpool John Moores University, Liverpool, UK \\ Email: *chrisbagley2@gmail.com
}

How to cite this paper: Shahnaz, A., Bagley, C., Simkhada, P. and Kadri, S. (2017) Suicidal Behaviour in Bangladesh: A Scoping Literature Review and a Proposed Public Health Prevention Model. Open Journal of Social Sciences, 5, 254-282.

https://doi.org/10.4236/jss.2017.57016

Received: June 2, 2017

Accepted: July 16, 2017

Published: July 19, 2017

Copyright ( 92017 by authors and Scientific Research Publishing Inc. This work is licensed under the Creative Commons Attribution International License (CC BY 4.0). http://creativecommons.org/licenses/by/4.0/

\begin{abstract}
The objectives of this review are to explore through a scoping analysis of published literature, the prevalence of suicidal ideation, attempts and suicide, and the correlates and presumed causes of such behaviours in Bangladesh, in order to develop a model of public health research and prevention. This type of review aims to contextualise existing knowledge, set it within a practice and policy context, and make recommendations for health care service delivery and evaluation. The evidence indicates an unusual pattern of completed suicide rates, those most at risk being younger women. The rate in adolescent girls is exceptionally high by international standards, and appears to reflect poverty, the low status of women, violence directed against girls and women, and forced marriages of young, teenage girls.
\end{abstract}

\section{Keywords}

Bangladesh, Scoping Review, Suicidal Behaviours, Adolescents, Child Marriage, Public Health, Suicide Prevention

\section{Introduction and Overview}

In this paper we briefly describe the geography, demographics and social structure of Bangladesh, a "low, middle-income" country which has many health related problems including those associated with high levels of morbidity and premature mortality in various disadvantaged groups. Suicidal behaviours have not been extensively studied in Bangladesh, and mental health issues have a generally low priority in research and prevention, given both the stigma associated with mental illness, and the demands on limited health care budgets. We begin by establishing the definitions of "suicidal behaviour" which have emerged in western research in the past 30 years, and problems and issues in defining and 
measuring suicidal behaviours. Because of these problems of calculating rates accurately, the differences recorded in the literature are likely to underestimate levels of suicidal behaviour in Bangladesh.

Bangladesh shows the unusual pattern of the highest rates of completed suicide being recorded in young females, including girls aged 12 to 19 . We identify in this review the high proportion of young girls either who never enter high school, or whose education is terminated, in order to force them into marriages to older men. Young girls in very poor families (at least a 30 percent of the Bangladeshi population) are often subject to violence both before and after their early marriages. We argue, from the epidemiological and clinical evidence, that adolescent female suicidal behaviours are a significant outcome of these violated lives. This is not the only cause of suicidal behaviour in Bangladesh, as the case study evidence and the statistical studies reviewed below. We propose public health prevention models for suicidal behaviour which are grounded within the Islamic culture of Bangladesh.

\section{Challenges in the Measurement of "Suicidal Behaviour"}

We use the term "suicidal behaviour", following Kreitman and Colleagues [1] [2] who originally coined the term "parasuicide", which researchers now refer to as "suicidal behaviour", as a generic definition which includes a series of actions, which are to a significant degree, linked to one another. These begin with suicidal intentions ("suicidal ideation") without any gesture or attempt having taken place-these thoughts and plans are not always communicated to others; then are suicidal gestures and self-harm in which the intention is probably not to die, but rather, the action represents a form of communication or "cry for help", or a symbolic gesture of self-punishment; then come more serious suicidal attempts in which there is a clear intention to die, or a potentially lethal method was used, or both; and finally completed suicide. In some cases however a person makes a serious attempt, or actually kills themselves without prior suicidal behaviours, or warnings to others. This means that although the best predictor of completed suicide is a previous, serious suicide attempt, the correlation is by no means perfect, and there are many "false negatives" and "false positives". This is a classic problem in social psychiatry [2], and is a challenge for public health: we know that some completed suicides can never be prevented.

There is also a dynamic challenge in the different kinds of suicidal behaviour. For therapeutic systems, in order for an action to be "suicidal" there must be suicidal thoughts (sometimes communicated to others) which precede that action. Surveys of adolescent populations show that up to a fifth of all teenagers will have had thoughts about suicide in the past year, some making active plans [3]. Suicidal gestures (acting on suicidal thoughts and plans) may involve up to 10 percent of all adolescents [4], although the large majority will not go on to make a more serious attempt, and may not possess a clear intent to die. Nevertheless, a history of suicidal gestures is a statistically significant predictor of a later serious suicide attempt. Individuals who have made several suicide at- 
tempts are at significant risk for completed suicide [5] [6]. In young adults (15 to 35 years) actual suicide attempts have become more common, and are key indicators of further suicidal risk, as well as the need for social and psychological interventions [7]. There are numerous points in this dynamic cycle for therapeutic intervention, before the individual moves into the more serious "psychological zone" of suicide risk [8].

While these models are based on Western research, they have, for example, been adopted with some success in Hong Kong, where a crucial task for mental health professionals has been to identify suicidal risk at an early stage, preventing the movement of individuals to the more serious plateau of suicidal risk [3]. Suicidal behaviours occur through the intersection of multiple disposing factors (psychological, social, psychiatric) and their expression and salience is mediated by differences in cultural norms and values [9]. That suicidal behaviours have such a complex set of causes, means that prevention programmes face multiple challenges [10] [11].

All "suicidal behaviours" (ideas, gestures, attempts, successful self-killing) are likely to be undercounted by medical agencies, and also in research studies, since protocol for deciding on "completed suicide" differ between legal systems and political cultures, and in some jurisdictions what might be an act of deliberate self-killing may be recorded as an "open or unknown" or "accidental death" in another jurisdiction ${ }^{1}$.

Researchers on aspects of suicidal behaviour in Bangladesh have made attempts to standardise methods of deciding on "suicide" using various methodologies [12] [13] [14] [15]. In international comparisons it is now customary to merge rates of "completed suicide" with rates of "open verdicts", since this latter category often includes individuals who have killed themselves [16]. Other workers have included the category of "careless death" within the broad category of "suicidal behaviour" [17].

\section{Suicidal Behaviour as a World-Wide Public Health Problem}

Although many acts of suicide are preventable, every 40 seconds a person dies by "suicide" somewhere in the world, and there are many more suicidal attempts for each death: at least half of these acts of self-injury and self-killing are preventable [18]. Approximately 804,000 formally recorded suicide deaths occurred worldwide in 2012, which represents an annual global age-standardized suicide rate of 11.4 per 100,000 population, 15.0 for males and 8.0 for females (almost certainly, these figures are underestimates).

Globally suicide has been identified as the fifteenth leading cause of death, and is the second in rank as a cause of death among young people aged $15-29$ years.

${ }^{1}$ In isolated rural settings in many developing countries, a self-killing may be seen as a tragic event, and the deceased will be buried or cremated. But the family may have no incentive to inform the authorities of the death, for reasons of shame or pity. That death will never enter the statistics of suicide. Or because of Islamic proscriptions concerning suicide, an "open" verdict will be reached, a more common practice in Muslim-majority countries than elsewhere. Thus completed suicide in women may be "undercounted" in some Muslim cultures, for cultural reasons. 
In wealthier countries, many more men die than women, WHO data showing that three times as many men die of suicide than do women. On the other hand, in low- and middle-income countries (LMIC) 1.5 males die of recorded suicide, for each woman counted [18]. The absolute number of recorded suicides in the world has fallen from 883,000 to 804,000 , a nine percent reduction in suicidal deaths in the period 2000-2012 [18]. Whether this recording pattern reflects a growing concern with WHO-sponsored public health interventions is not clear. However, the World Health Organization has developed a Mental Health Action Plan with the goal of reducing the rate of suicide globally by 10 percent by 2020 [18].

Every suicide is likely to have a major impact on a family's wellbeing, and may in fact reflect a family's stressed situation: the suicide of a parent or child will likely add to that stress [5]. It has been established that knowing someone who has killed themselves is a risk factor, so suicides may occur in "clusters", in kinship groups, communities, schools, or other institutions [4]. Family and community support in the wake of a self-killing is of crucial importance. However, when the deceased person was overtly mentally ill, the stigma attached to mental disorders and suicides can be a strong obstacle both for suicide prevention, and post-trauma counselling for survivors, especially in low- and middle-income countries [9].

\section{The Cultural Context of This Review-Bangladesh}

Bangladesh is a relatively small country in south Asia, but is also one of the most densely populated, with 166 million people living in a space of 147,570 sq. km. The country is surrounded by India, with a small common border with Myanmar in the southeast, and access to the ocean in the Ganges delta. The majority (89\%) of the people are nominally Muslim; the second largest religious affiliation is Hinduism. More than 75 percent of the population live, albeit in crowded circumstances, in rural areas [19]. Income inequality is high, and is increasing [20], and 31 percent of around 43.2 million people in the lowest income sector live in extreme poverty, with incomes equivalent to $\$ 2$ a day, or less. Poverty is associated with poor maternal and child health, and the health gap between economically advantaged and economically poor children in terms of stunted growth in children is actually increasing [21]. Tropical monsoons and frequent floods and cyclones inflict heavy damage on infrastructure and agriculture almost every year.

As in many other developing countries, a patriarchal social system is dominant. Women are subordinated to men both within the household, and in society at large, often in contradiction of Qur'anic, Sunnah and Sharia principles [22] [23] [24]. These folk-based (rather than religious-based) cultural normative structures surround the unequal treatment of children (i.e. a bias against the status and care of females), and continue through to old age. Gender inequality and discrimination against women is a common (but rarely discussed) factor in Bangladesh society [23]. Early marriage of female children is a major problem. Nearly two-thirds of girls are married before the age of eighteen and in many 
areas more than a quarter of girls are married before they reach fifteen, the highest proportion of child marriages in South Asia. Despite national legislation, the rate of child marriage is perpetuated by poverty linked with a traditionally patriarchal society, in rural areas, and in the rural to urban migrants living in slum dwellings in cities [25]. For very poor families, female children are often considered to be an economic burden. Thus for families living in extreme poverty, marrying daughters to older men is often a survival strategy. Dowry payments (from the female's family to the husband) are common in Bangladesh, and are lower when girls are younger.

Rural to urban migration of the very poor is common, with millions living in makeshift dwellings on the periphery of cities [25] [26]. These slums are marked by extreme poverty, lack of clean water and waste management, malnutrition, and high rates of disease and early death [25]. Social integration is poor, education and school buildings are lacking, and religious socialization in basic values is often absent, since there are rarely mosques or madrassas (schools for religious instruction) in these slum areas. According to the ethnographic work of Das, lives are marked by pre-Islamic rituals grounded in despair and fatalism. Islam forbids the sacrifice of female children, but one means to family survival is to sell female children to one of the many urban brothels [26] [27].

\section{Suicidal Behaviours in Asia}

Suicide is a major public health problem in Asia, where the suicide rate surpasses the global average. Roughly 60 percent of globally recorded suicide occurs in Asia [28]: India, China, and Japan contribute about 40 percent of all recorded, completed suicides in the world [29], not because of high suicide rates, but because of their large population size. In Asia, suicide rates are higher in the South Asian region [30]. Suicide rates in India vary between 8.1 and 58 per 100,000, depending on the state or region within a state [31]. In Sri Lanka, the rate was found to be exceptionally high at 37 per 100,000 population [32] [33]. Similar burdens of suicidal deaths have been observed in Nepal with a rate of 24.9 per 100,000 (rates for men and women being 30.1 and 20.0 per 100,000 respectively $)^{2}$. It has been further observed that unmarried women aged $10-24$ years are at most risk of suicide in Nepal [34].

In most high-income countries, mortality reporting systems are well established, but this aspect of health surveillance is generally not adequately addressed in many public health systems in Lower and Middle-Income Countries-LMICs [35]. Suicide deaths mainly occur at home, and indeed some deaths may be unreported (especially in the case of infants) so information about cause of death in official statistics is often absent or unreliable. Suicide is a sensitive issue for many cultures, and in some cases the act is illegal [18]. In some LMICs national suicide data are not available, and if available their validity might be questionable [30] [36]. It may be that especially in LMICs, the actual completed suicide rate is significantly higher than the recorded one, while that in developed countries with their well-deve-

${ }^{2}$ http://apps.who.int/gho/data/node.main.MHSUICIDE?lang=en (accessed on the 11 February 2017). 
loped coroner and medical examiner systems is more likely to be accurate. If that is the case, reported differences in rates between developed and developing countries will be higher than currently estimated.

\section{Suicidal Behaviors and Violent Deaths in Bangladesh}

Suicide takes approximately 10,000 lives each year, and is one of the major causes of death in young adult females in Bangladesh [35]. Although the overall estimated average rate of suicide in Bangladesh is 7.3 per 100,000 of the population per year, the rate in adolescents (15 - 19 years) is much higher, at 17.1 in males, and 22.7 per 100,000 in females [35] [37]. These figures are likely to be an underestimate, since most of these deaths occur in rural areas where procedures for legal and medical surveillance of premature deaths are not well-developed. "Bangladesh is an Islamic country and socially and religiously suicide is stigmatising, therefore suicide deaths might be hidden by the family." [35]. This idea is supported by Canetto's international survey of suicide rates in women in Muslim countries [38].

It is notable that contrary to the global pattern, the suicide rate for females in all age groups (8.2 per 100,000 populations) is higher than in males (6.5 per 100,000 population) in Bangladesh [35]. Adolescent females (10 - 19 years) were found to be the most vulnerable with the rate of suicide of around 20 per 100,000 in rural areas [35]. These rates resemble the age-sex specific suicide risk in Nepal [34]. The suicide rate in Bangladesh is 17 -fold higher (95\% CI 5.36 - 54.6) in the rural population than in urban areas [35].

Mental illness is widely cited as a potential correlate or risk factor for suicide in developed countries, and up to 90 percent of suicides are said to be linked to depression, substance abuse or psychosis [39]. However, this link may in part be artefactual, in that a verdict of "suicide" may be reached only after prima facie evidence of mental disorder is available [40]. But since in many other LMICs such as Bangladesh, mental health is not prioritized by the government (with only $0.5 \%$ of total health expenditure allocated to mental health, there being no specific mental health authority in that country) construing suicide as a sequel of mental illness, may not dominate the conceptual frameworks of officials designating cause of death.

In LMICs, only some four percent of doctors and two percent of nurses are trained in mental health care [40]. The situation in Bangladesh is not likely to be any better. In the general population and at the governmental level, being psychiatrically ill is likely to be a highly stigmatised status, associated with shame for the family, and neglect by health and social services. The extreme despair which drives the individual to self-killing may be linked to unrecognised or untreated endogenous illnesses (e.g. clinical depression, or psychosis); or it may have psychosocial causes within the social system, such as the very low status of girls and young women, and the frequent violence and forced marriage at a very young age, within families whose overwhelming problems are those caused by extreme poverty [37] [41]. 


\section{Objectives of the Review}

The objectives of this review are to explore through a scoping analysis of published literature, the prevalence of suicidal ideation, attempts and suicide, and the correlates and presumed causes of such behaviours in Bangladesh, in order to develop a model of public health research and prevention, following the guidelines of Anderson and Colleagues [42]. This type of review aims to contextualise existing knowledge, setting it within a practice and policy context, and making recommendations for health care service delivery and evaluation.

\section{Methods of Review}

This scoping review was conducted of peer-reviewed publications and "grey" literature. Published studies and reports were identified through a systematic search. To identify peer-reviewed publications we searched online databases PsycINFO, PubMed, EMBASE and CINAHL. The search terms we used were: ["suicide"/exp OR "suicide" OR "suicidal ideation"/exp OR "suicidal ideation" OR "suicide attempts" OR "suicidal behaviour"/exp OR "suicidal behaviour" OR "suicidal thought" OR "self harm"/exp OR "self harm" AND ("bangladesh"/exp OR bangladesh)]. The search included all publications indexed, at any time. The search was performed in January 2017.

After inspection of title, abstract and any keywords, the full text of selected studies was assessed for relevance for the scoping review, which explored the questions: What is the knowledge base concerning suicidal behaviours in Bangladesh? And how can this knowledge inform public health programmes which aim to diminish rates of various kinds of suicidal behaviour?

All publications that were eligible for full review were cross-referenced. The review focuses on all published literature that has included Bangladesh as the source of clinical material, or has included Bangladesh in comparative work ${ }^{3}$. All of these reports are in the English language, and no studies in the local language (Bangla) could be located. No work published in a European language other than English could be found. Purely clinical studies (e.g. a single case report of an unusual method of suicide), which did not adequately address any suicide-related epidemiology or risk factors, were not included. Once a relevant abstract was located, the full text was consulted.

Details of each study were analysed using a standardized data extraction form, focusing on: Study details (dates, any follow-up); Study design; Population details (numbers, characteristics); Settings; Context details; Outcomes and findings; Conclusions and recommendations.

The following outcomes were recorded: Rates of suicide, suicidal attempts, suicidal ideation; Patterns of suicide and suicidal attempts; Socioeconomic and demographic factors of suicide and suicidal behaviour in both rural and urban

${ }^{3}$ There is another kind of literature which focusses on Bangladeshi migrants living outside of their mother country. For a review of this literature (which implies that Bangladeshi women in Britain have higher rates of mental illness and suicidal behaviours than Bangladeshi males, several years after leaving Bangladesh) see Bagley [43]. These studies are not included in the present review. 
settings; Reasons and risk factors thought to underlie suicidal ideation, suicidal attempts and suicide, among different age groups.

The "Strengthening the Reporting of Observational Studies in Epidemiology" (STROBE) statement has been applied, in attempting to arrive at an accurate and complete report of identified studies for this systematic review. We used the STROBE statement developed by Von Elm and Colleagues [44]. According to STROBE, studies should be classified into three types considering the study design (cohort, case-control and cross-sectional) to explore the scope of the recommendations. STROBE identifies 22 items that relate to the title, abstract, introduction, methods, results, and discussion sections of articles. 18 items are common to all three study designs and four are specific for cohort, case-control, or cross-sectional studies.

\section{Final Selection of Studies for Scoping Review}

Initially 563 research papers were identified using electronic database and grey literature. After examined the title 478 were excluded due to their irrelevance and 85 studies were primarily selected. Out of 85 studies 44 were duplicates across databases. For abstract screening 41 research papers were selected and after reading the abstracts 5 studies were excluded. The remaining 36 articles were selected for reading full text, of which full text was not available for 3 articles. Rest of the 33 articles were read and quality assessed. Of these, 10 articles failed to meet the quality assessment and inclusion criteria and 23 article were finally selected for the review. Figure 1 shows the flow chart of the systematic selection of finally included studies in this review.

\section{Results of Analyses of Published Studies}

A total of 23 articles were selected for final review. These studies were based ei-

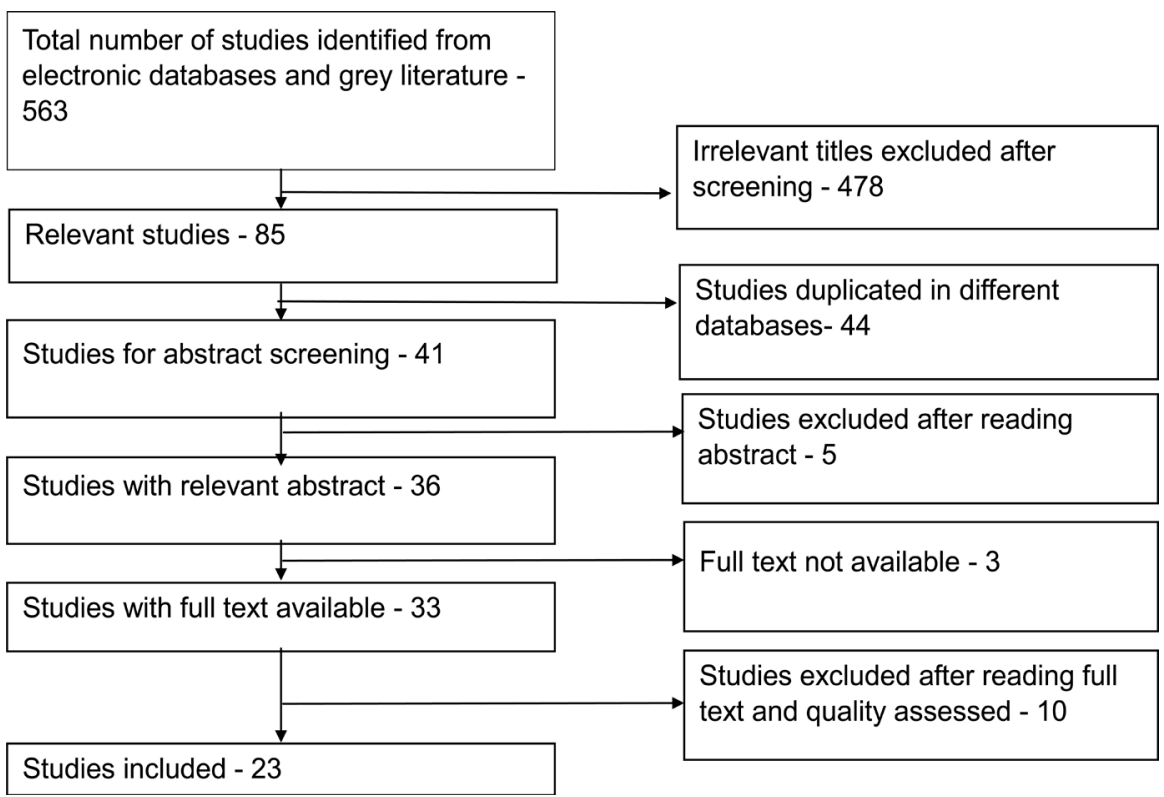

Figure 1. Flow chart of systematic literature selection for review. 
Table 1. Distribution of studies included in the review based on study designs and locations.

\begin{tabular}{cccc}
\hline \multirow{2}{*}{ Study design } & \multicolumn{3}{c}{ Setting } \\
\cline { 2 - 4 } & Hospital-based & Community/population-based & Number of studies \\
Case-control & - & 2 & 2 \\
Cross-sectional & 4 & 7 & 11 \\
Cohort & - & 1 & 1 \\
Cross-sectional time-series & 1 & 5 & 6 \\
Case-findings approach & 2 & - & 2 \\
Literature review & - & - & 1 \\
Total & 7 & 15 & 23 \\
\hline
\end{tabular}

ther on hospital area populations, or in the community, and employed six different types of study design (Table 1). Most of the studies were cross-sectional (10 out of 23), followed by cross-sectional time-series (6 out of 23). One literature review was found. Ten additional studies were excluded because of their clinical focus (e.g. single case reports), or because of inadequate methodology, and/or publication in unknown or non-standard journals.

Community or population-based studies are predominant, in 14 out of 23 studies (see Table 1). We have classified studies into three types, considering the outcome variables and study settings.

In Table 2, we summarize the selected studies which focussed on suicidal ideation and attempts. All of these studies were conducted in the community. Table 3 and Table 4 summarize the studies with completed suicide as outcomes; Table 3 reflects the studies conducted in community, and Table 4 those on hospital populations. Further, our review sought to extract knowledge about reasons for suicide in Table 5 .

\subsection{Prevalence of Suicidal Ideation and Attempts}

Table 2 indicates that all but one of the five studies were conducted in rural areas. One study investigated six countries including Bangladesh, examining both urban and rural populations [45]. Three studies included women of "reproductive age" (15 - 49 years). The sample sizes varied between 361 and 24,097. In one study 33 percent of the pregnant women studied reported depression, with 17 percent of the total population expressing suicidal ideation [46]. Another study observed that amongst ever-married women in Bangladesh 21 percent who experienced sexual and/or physical violence in their lives (compared with 7\% who did not) reported that they had considered committing suicide [45]. These findings clearly imply that the experience of physical and sexual violence contributes to suicidal ideation amongst younger married women. The study of Naved \& Akhtar [47] investigated possible reasons behind suicidal ideation in women aged 15 to 49 , and report that 12 percent of ever married women (in their stratified random sample of 2702 individuals in rural and urban areas) reported the 
experience of suicidal ideas and thoughts in their lifetime, 5 percent in the previous month, a much higher proportion than in women in other developing countries considered. Women who reported physical violence by their husbands were twice as likely to say they had thoughts about killing themselves.

Wahlin and Colleagues [12] using the SRQ20 psychiatric screening instrument in a rural area in those aged 60 - 95 years, found that 45 percent manifested "depression", and 23 percent had "thoughts about suicide". These rates are higher than those of depression among reproductive age women in the study of Gausia and Colleagues [46]. The instrument used in the latter study was however the EPDS-B, and the comparative validity of the two instruments (SRQ and EDPS) used is unknown in Bangladesh, although validity studies are available from other LMIC [48]. The SRQ20 (a WHO-recommended instrument for screening for

Table 2. Prevalence of suicidal ideation and attempts.

\begin{tabular}{|c|c|c|c|c|c|c|c|}
\hline $\begin{array}{c}\text { Authors and } \\
\text { publication } \\
\text { years }\end{array}$ & $\begin{array}{l}\text { Year of data } \\
\text { collection }\end{array}$ & Settings & Place of the study & Age and sex & N sample size & $\begin{array}{l}\text { Outcome } \\
\text { measures } \\
\text { instruments }\end{array}$ & Prevalence \\
\hline $\begin{array}{l}\text { Ellsberg et al. } \\
2008\end{array}$ & $2000-2003$ & $\begin{array}{l}\text { Urban } \\
\text { or/and } \\
\text { Rural }\end{array}$ & $\begin{array}{l}\text { Bangladesh, Brazil, } \\
\text { Peru, Thailand, } \\
\text { Tanzania, Ethiopia, } \\
\text { Japan, Namibia, and } \\
\text { Serbia and } \\
\text { Montenegro, Samoa }\end{array}$ & $\begin{array}{l}15 \text { - } 49 \text { years } \\
\text { ever-married } \\
\text { women }\end{array}$ & 24,097 & $\begin{array}{l}\text { A standardized } \\
\text { questionnaire was } \\
\text { developed, and } \\
\text { translated into } 14 \\
\text { languages }\end{array}$ & $\begin{array}{l}\text { Average prevalence of } \\
\text { suicidal ideation for all } \\
\text { countries was } 2.9(2.7-3.2) \text {. } \\
\text { In Bangladesh suicidal } \\
\text { ideation was } 7 \% \text { and } 21 \% \text { for } \\
\text { ever-married women who are } \\
\text { without and with experience } \\
\text { of physical and sexual } \\
\text { violence respectively. }\end{array}$ \\
\hline $\begin{array}{l}\text { Feroz et al. } \\
2012\end{array}$ & $\begin{array}{l}\text { from } \\
15 / 12 / 2009 \text { to } \\
15 / 03 / 2010\end{array}$ & Rural & $\begin{array}{l}\text { Mominpur union } \\
\text { under Sadar Upazilla } \\
\text { of district, } \\
\text { Chuadanga }\end{array}$ & $\begin{array}{l}12-70 \text { years } \\
\text { male and } \\
\text { female }\end{array}$ & $\begin{array}{l}\text { A total of } 3551 \\
\text { households } \\
\text { were surveyed } \\
\text { covering 12,422 } \\
\text { individuals. }\end{array}$ & $\begin{array}{l}\text { Door-to-door } \\
\text { survey, face to } \\
\text { face interview and } \\
\text { recording of all } \\
\text { findings. }\end{array}$ & $\begin{array}{l}\text { Prevalence of suicidal } \\
\text { attempt was } 281.8 \text { per } \\
100,000 \text { per year }\end{array}$ \\
\hline $\begin{array}{l}\text { Naved and } \\
\text { Akhtar } 2008\end{array}$ & $\begin{array}{l}\text { June } 25 \\
\text {-November 25, } \\
2001\end{array}$ & Rural & $\begin{array}{l}\text { National } \\
\text { representative }\end{array}$ & $\begin{array}{l}\text { Women } \\
15-49\end{array}$ & 2,702 & $\begin{array}{l}\text { Structured } \\
\text { questionnaire }\end{array}$ & $\begin{array}{l}\text { Prevalence of suicidal } \\
\text { ideation was } 11 \%-14 \% \text {. } \\
\text { About } 5 \%-6 \% \text { of the } \\
\text { ever-married women } \\
\text { reported having suicidal } \\
\text { ideation during the last } 4 \\
\text { weeks. }\end{array}$ \\
\hline $\begin{array}{l}\text { Wahlin et al. } \\
2015\end{array}$ & $\begin{array}{l}\text { August } \\
\text { 2003-January } \\
2004\end{array}$ & Rural & $\begin{array}{l}\text { Matlab sub-district } \\
\text { in Chandpur }\end{array}$ & $\begin{array}{l}60 \text { - } 95 \text { years } \\
\text { man and } \\
\text { woman }\end{array}$ & 625 & $\begin{array}{l}\text { SRQ20 (self } \\
\text { reporting } \\
\text { questionnaire 20) }\end{array}$ & $\begin{array}{l}\text { The prevalence of depression } \\
\text { was } 45 \% \text {, and most } \\
\text { pronounced among the } \\
\text { oldest women }(70 \%) \text {. The } \\
\text { prevalence of suicidal } \\
\text { ideation was } 23 \% \text { (men } 17 \% \\
\text { and women } 28 \% \text { ) }\end{array}$ \\
\hline
\end{tabular}


Table 3. Prevalence of suicide in community-based population-based studies.

\begin{tabular}{|c|c|c|c|c|c|c|c|}
\hline $\begin{array}{l}\text { Authors and } \\
\text { publications } \\
\text { years }\end{array}$ & $\begin{array}{l}\text { Year of } \\
\text { data } \\
\text { collection }\end{array}$ & Settings & $\begin{array}{l}\text { Place of } \\
\text { the study }\end{array}$ & Age and sexes & N sample size & $\begin{array}{l}\text { Outcome measures } \\
\text { instruments }\end{array}$ & Prevalence of suicide \\
\hline $\begin{array}{l}\text { Alam et al. } \\
2014\end{array}$ & $2004-2010$ & Rural & $\begin{array}{l}\text { Abhoynagar } \\
\text { and Mirsarai }\end{array}$ & $\begin{array}{l}\text { All ages and } \\
\text { sexes }\end{array}$ & $\begin{array}{l}\text { Abhoynagar }=1384 \\
\text { Mirsarai }=1847\end{array}$ & Verbal autopsy. & $\begin{array}{l}\text { Intentional self-killing (suicide) rate of } \\
\text { all ages and sexes in Abhoynagar was } \\
3.5 \% \text { and in Mirsarai was 1.5\%; suicide } \\
\text { rate for women in Abhoynagar was } \\
5.1 \% \text { and in Mirsarai was } 2.5 \% \text {. }\end{array}$ \\
\hline $\begin{array}{l}\text { Ahmed et al. } \\
2004\end{array}$ & $1982-98$ & Rural & Matlab & $\begin{array}{l}\text { Women at } \\
\text { reproductive } \\
\text { age ( } 15-44 \\
\text { years) }\end{array}$ & $\begin{array}{l}\text { All deaths from violence } \\
\text { (117 cases) and other } \\
\text { causes (1181 cases) in } \\
\text { 1982-1998 were included } \\
\text { as cases. Roughly the same } \\
\text { number of surviving } \\
\text { women of reproductive age } \\
\text { in 1982-1998 were } \\
\text { included as controls (1235) }\end{array}$ & $\begin{array}{l}\text { Data analysed from } \\
\text { registration forms of } \\
\text { the population-based } \\
\text { demographic } \\
\text { surveillance system }\end{array}$ & $\begin{array}{l}\text { The suicide rate of women was } \\
\text { considerably higher than men ( } 13 \text { vs } 8 \\
\text { per } 100,000 \text { person-years). } \\
\text { Ill-treatment by husband and/or } \\
\text { in-law(s) ( } 41.7 \% \text { ) was the main reason } \\
\text { of suicide among married women. }\end{array}$ \\
\hline $\begin{array}{l}\text { Fauveau and } \\
\text { Blanchet, } \\
1989\end{array}$ & $1976-1986$ & Rural & $\begin{array}{l}\text { Matlab } \\
\text { sub-district }\end{array}$ & $\begin{array}{l}15-44 \text { years } \\
\text { women }\end{array}$ & $\begin{array}{l}1139 \text { female deaths at age } \\
15 \text { - } 44 \text { years during } \\
1976-1986 \text { in Matlab. }\end{array}$ & Verbal autopsy & $\begin{array}{l}\text { Of total } 1139 \text { deaths } 207 \text { deaths were } \\
\text { from intentional and unintentional } \\
\text { injuries. } 4.9 \% \text { were due to suicide } \\
\text { ( } 3.4 \% \text { by poisoning and } 1.5 \% \text { by } \\
\text { hanging). }\end{array}$ \\
\hline Hadi 2005 & 1990-99 & Rural & $\begin{array}{l}70 \text { villages } \\
\text { from } 10 \\
\text { districts }\end{array}$ & $\begin{array}{l}\text { All ages and } \\
\text { sexes }\end{array}$ & Nearly 62,000 & $\begin{array}{l}\text { A standard verbal } \\
\text { autopsy procedure was } \\
\text { used to identify the } \\
\text { causes of death. }\end{array}$ & $\begin{array}{l}\text { Of total } 175 \text { deaths } 6.6 \% \text { were due to } \\
\text { suicide. Among male } 4.2 \text { and among } \\
\text { female } 8.9 \text { per } 100,000 \text { population } \\
\text { committed suicide. }\end{array}$ \\
\hline $\begin{array}{l}\text { Mashreky } \\
\text { et al. } 2011\end{array}$ & $\begin{array}{l}\text { January- } \\
\text { December } \\
2003\end{array}$ & Urban and rural & $\begin{array}{l}\text { National } \\
\text { representative }\end{array}$ & $\begin{array}{l}\text { All ages and } \\
\text { sexes }\end{array}$ & $\begin{array}{l}\text { Total sample size was } \\
171,366 \text { households from } \\
\text { total population of } 819,429 \\
\text { of which } 88,380 \text { from rural } \\
\text { areas, } 45,183 \text { from district } \\
\text { towns (urban areas) and } \\
37,803 \text { from Dhaka } \\
\text { Metropolitan City. }\end{array}$ & $\begin{array}{l}\text { Face-to-face } \\
\text { interviews at a } \\
\text { household level }\end{array}$ & $\begin{array}{l}\text { One suicide case of total } 18 \text { burn case } \\
\text { which constituted about } 5 \% \text { of the } \\
\text { total number of burn deaths. }\end{array}$ \\
\hline $\begin{array}{l}\text { Mashreky } \\
\text { et al. } 2013\end{array}$ & & $\begin{array}{l}\text { Urban and rural } \\
\text { areas of } 12 \\
\text { randomly selected } \\
\text { districts of } \\
\text { Bangladesh and } \\
\text { Dhaka } \\
\text { Metropolitan City. }\end{array}$ & $\begin{array}{l}\text { National } \\
\text { representative }\end{array}$ & $\begin{array}{l}\text { All age-groups } \\
\text { and sexes }\end{array}$ & $\begin{array}{l}\text { Total sample size was } \\
171,366 \text { households from } \\
\text { total population of } 819,429 \\
\text { of which } 88,380 \text { from rural } \\
\text { areas, } 45,183 \text { from district } \\
\text { towns (urban areas) and } \\
37,803 \text { from Dhaka } \\
\text { Metropolitan City. } \\
\text { Bangladesh }\end{array}$ & $\begin{array}{l}\text { Face-to-face } \\
\text { interviews at a } \\
\text { household level }\end{array}$ & $\begin{array}{l}\text { Suicide rate was } 7.3 \text { ( } 95 \% \text { CI } 5.6 \text { - } 9.5 \text { ) } \\
\text { per } 100,000 \text { per year. The highest rate } \\
\text { was found in the age group of } 60> \\
\text { years. } 17 \text {-fold higher ( } 95 \% \text { CI } 5.36 \text { - } \\
54 . \text { ) in the rural than urban } \\
\text { population. Adolescent suicide rate in } \\
\text { rural areas was } 20.1 \text { ( } 95 \% \text { CI } 12.6 \text { - } \\
31.7 \text { ) per } 100,000 \text {. The rate was } 17.7 \\
(95 \% \text { CI } 8.6 \text { - } 34.9 \text { ) and } 22.7 \text { ( } 95 \% \text { CI } \\
12 \text { - } 42 \text { ) among males and females } \\
\text { respectively. }\end{array}$ \\
\hline $\begin{array}{l}\text { Nahar et al. } \\
2015\end{array}$ & $\begin{array}{l}2001 \text { and } \\
2010\end{array}$ & $\begin{array}{l}\text { Urban and rural, } \\
\text { countrywide }\end{array}$ & $\begin{array}{l}\text { National } \\
\text { representative }\end{array}$ & $\begin{array}{l}10-49 \text { years } \\
\text { old females }\end{array}$ & $\begin{array}{l}100,000 \text { in } 2001 \text { and } \\
174,000 \text { in } 2010\end{array}$ & Verbal autopsy & $\begin{array}{l}\text { Total reported deaths were } 696 \text { and } \\
749 \text { cases in } 2001 \text { and } 2010 \\
\text { respectively. Suicide accounted for } 23 \\
\text { cases per } 100,000 \text { in } 2001 \text { and } 16 \text { per } \\
100,000 \text { in } 2010 \text {. }\end{array}$ \\
\hline
\end{tabular}




\section{Continued}

\begin{tabular}{|c|c|c|c|c|c|c|c|}
\hline $\begin{array}{l}\text { Reza et al. } \\
2013\end{array}$ & $\begin{array}{l}15 \\
\text { December } \\
2009 \text { to } 15 \\
\text { March } \\
2010\end{array}$ & Rural & $\begin{array}{l}\text { Mominpur, } \\
\text { Haowlee and } \\
\text { Jibonnagar } \\
\text { unions under } \\
\text { three Upazilla } \\
\text { of district } \\
\text { Chuadanga. }\end{array}$ & $\begin{array}{l}\text { All ages and } \\
\text { sexes }\end{array}$ & $\begin{array}{l}230 \text { ( } 113 \text { cases and } 117 \\
\text { controls) }\end{array}$ & $\begin{array}{l}\text { Interviewed by } \\
\text { experienced } \\
\text { clinicians using The } \\
\text { Structured } \\
\text { Clinical Interview for } \\
\text { DSM-IV Axis I } \\
\text { Disorders (SCID-I) }\end{array}$ & $\begin{array}{l}\text { Risk factors for suicidal attempts were } \\
\text { analysed. Most significant risk factors } \\
\text { for suicidal attempts were found as } \\
\text { "conflict within the family with a OR } \\
\text { of } 6.9 \text { and "uncertainty about future" } \\
\text { with a OR of } 7.2 \text {. }\end{array}$ \\
\hline $\begin{array}{l}\text { ICDDRB, } \\
\text { Health and } \\
\text { Science } \\
\text { Bulletin } \\
(2003) \text {. }\end{array}$ & $1983-2002$ & $\begin{array}{l}\text { Rural and } \\
\text { semi-urban }\end{array}$ & $\begin{array}{l}\text { Abhoynagar } \\
\text { and } \\
\text { Keshobpur } \\
\text { rural and } \\
\text { semi-urban } \\
\text { sub districts of } \\
\text { Jessore district } \\
\text { in southwest } \\
\text { Bangladesh }\end{array}$ & $\begin{array}{l}\text { All ages and } \\
\text { sexes }\end{array}$ & 3237 deaths & Verbal Autopsy & $\begin{array}{l}\text { Mortality from suicide occurred at a } \\
\text { rate of } 39.6 \text { per } 100,000 \text { population per } \\
\text { year from } 1983-2002 \text {. Among young } \\
\text { people } 10 \text { - } 19 \text { years old, suicide rate } \\
\text { was } 42 \text { per } 100,000 \text { population and } \\
89 \% \text { of them are female. }\end{array}$ \\
\hline $\begin{array}{l}\text { Jordans et al. } \\
2014\end{array}$ & $\begin{array}{l}\text { Electronic } \\
\text { database } \\
\text { search for } \\
\text { scoping } \\
\text { review } \\
\text { from } \\
1998-2012\end{array}$ & $\begin{array}{l}\text { All peer-reviewed } \\
\text { publications and } \\
\text { grey literature. }\end{array}$ & $\begin{array}{l}\text { Six countries } \\
\text { (Afghanistan, } \\
\text { Pakistan, Sri } \\
\text { Lanka, India, } \\
\text { Nepal and } \\
\text { Bangladesh) }\end{array}$ & $\begin{array}{l}\text { All ages and } \\
\text { sexes }\end{array}$ & $\begin{array}{l}\text { Various populations used in } \\
\text { different studies. }\end{array}$ & different methods & $\begin{array}{l}\text { The non-pooled mean rate of suicide } \\
\text { in Bangladesh is } 58.3(\mathrm{SD}=63.22) \text {. } \\
\text { Bangladesh reported inverse (unlike } \\
\text { other countries) male to female ratios, } \\
\text { i.e. more female suicide deaths than } \\
\text { male ( } 0.43: 1 \text { to } 0.83: 1 \text { ). }\end{array}$ \\
\hline
\end{tabular}

Table 4. Prevalence of suicide in hospital based studies.

\begin{tabular}{|c|c|c|c|c|c|c|c|}
\hline $\begin{array}{l}\text { Author's and } \\
\text { publications } \\
\text { years }\end{array}$ & $\begin{array}{l}\text { Year of data } \\
\text { collection }\end{array}$ & Settings & Place of the study & Age and sex & $\begin{array}{l}\text { N sample } \\
\text { size }\end{array}$ & $\begin{array}{l}\text { Outcome } \\
\text { measures } \\
\text { instruments }\end{array}$ & Prevalence of suicide \\
\hline $\begin{array}{l}\text { Chowdhury } \\
\text { et al. } 2011\end{array}$ & $\begin{array}{l}\text { January, } 2003 \text { - } \\
\text { December, } 2006\end{array}$ & Hospital & $\begin{array}{l}\text { Southern part of the } \\
\text { country }\end{array}$ & $\begin{array}{l}10 \text { years and } \\
\text { above of } \\
\text { both sexes }\end{array}$ & $\begin{array}{l}\text { Total } 1903 \\
\text { patients } \\
\text { with acute } \\
\text { poisoning }\end{array}$ & $\begin{array}{l}\text { Hospital } \\
\text { record review }\end{array}$ & $\begin{array}{l}\text { Of total } 1903 \text { cases, } 1308(68.7 \%) \text { were } \\
\text { suicide. }\end{array}$ \\
\hline $\begin{array}{l}\text { Hussain et al. } \\
2000\end{array}$ & 1996-97 & $\begin{array}{l}\text { Nation wide } \\
\text { health care } \\
\text { facilities }\end{array}$ & $\begin{array}{l}\text { Nationally representative } \\
\text { healthcare facilities }\end{array}$ & $\begin{array}{l}10-50 \text { years } \\
\text { old women }\end{array}$ & 28,998 & $\begin{array}{l}\text { Medical } \\
\text { records review }\end{array}$ & $\begin{array}{l}\text { Of total } 28,998 \text { identified deaths } 6610 \text { were } \\
\text { due to intentional or unintentional injuries. } \\
\text { Half of these ( } 3317 \text { ) occurred due to suicide. } \\
\text { The unadjusted rate of suicides were higher } \\
\text { in the Khulna administrative division }(27 \cdot 0 \\
\text { per } 100,000 \text { ) than the other four } \\
\text { administrative divisions of Bangladesh } \\
\text { (range } 3.5-11 \cdot 3 \text { per } 100,000 \text { ). }\end{array}$ \\
\hline $\begin{array}{l}\text { Hussain et a. } \\
2007\end{array}$ & $\begin{array}{l}\text { October } 1996 \text { - } \\
\text { March } 1997\end{array}$ & Hospital & $\begin{array}{l}\text { Country-wide study } \\
\text { covered } 4751 \text { facilities in } \\
\text { the country, including all } \\
\text { the } 13 \text { government } \\
\text { medical college hospitals, } \\
\text { five infectious disease } \\
\text { hospitals, and } 96 \\
\text { maternal and child } \\
\text { welfare centres. }\end{array}$ & $\begin{array}{l}\text { Deaths } \\
\text { among } \\
\text { women aged } \\
10-50 \text { years }\end{array}$ & $\begin{array}{l}28,998 \text { total } \\
\text { deaths }\end{array}$ & $\begin{array}{l}\text { Medical } \\
\text { records review }\end{array}$ & $\begin{array}{l}\text { Of total } 28,998 \text { deaths } 3116 \text { occurred by } \\
\text { suicide, accounting for } 10.7 \% \text { of all deaths. } \\
\text { Among women at age } 10 \text { - } 19 \text { years, suicide } \\
\text { accounted for } 21.7 \% \text { i.e. the highest among } \\
\text { all age groups ( } 20 \text { - } 29 \text { years: } 13.2 \%, 30 \text { - } 39 \\
\text { years: } 6.3 \% \text { and } 40 \text { - } 49 \text { years: } 2.9 \%) \text {. }\end{array}$ \\
\hline $\begin{array}{l}\text { Islam and } \\
\text { Islam, } 2003\end{array}$ & $\begin{array}{l}\text { January } 1988- \\
\text { December } 1997\end{array}$ & $\begin{array}{l}\text { Tertiary-level } \\
\text { hospital }\end{array}$ & $\begin{array}{l}\text { Sir Salimullah Medical } \\
\text { College Hospital, Dhaka }\end{array}$ & $\begin{array}{l}\text { All ages and } \\
\text { sexes }\end{array}$ & 2534 & $\begin{array}{l}\text { Verbal } \\
\text { Autopsy }\end{array}$ & $\begin{array}{l}18 \% \text { deaths were due to suicide, mainly by } \\
\text { poisoning, followed by hanging. Of total } \\
\text { suicide related deaths ( } 467), 45.8 \% \text { occurred } \\
\text { among females. }\end{array}$ \\
\hline $\begin{array}{l}\text { Khan et al. } \\
2013\end{array}$ & $\begin{array}{l}\text { January } 2012- \\
\text { April } 2012\end{array}$ & $\begin{array}{l}\text { Tertiary-level } \\
\text { hospital }\end{array}$ & $\begin{array}{l}\text { Mymensingh Medical } \\
\text { College Hospital }\end{array}$ & $\begin{array}{l}12 \text { years and } \\
\text { above, both } \\
\text { sexes }\end{array}$ & $\begin{array}{l}\text { Total } \\
\text { poisoning } \\
\text { cases }\end{array}$ & $\begin{array}{l}\text { Structured } \\
\text { questionnaire }\end{array}$ & $\begin{array}{l}\text { Suicidal attempt was } 81.6 \% \text { of total } \\
\text { poisoning cases. Organophosphorus was the } \\
\text { mostly used compound ( } 63.9 \%) \text { as poison. }\end{array}$ \\
\hline $\begin{array}{l}\text { Quader et al. } \\
2010\end{array}$ & $\begin{array}{l}\text { January } \\
\text { 2007-December } \\
2008\end{array}$ & $\begin{array}{l}\text { Tertiary-level } \\
\text { hospital }\end{array}$ & $\begin{array}{l}\text { Mymensingh Medical } \\
\text { College Hospital }\end{array}$ & $\begin{array}{l}\text { All ages and } \\
\text { sexes }\end{array}$ & $\begin{array}{l}692 \text { deaths } \\
\text { by } \\
\text { poisoning }\end{array}$ & Verbal autopsy & $\begin{array}{l}\text { Of total } 692 \text { deaths from poisoning, } 657 \\
(94.9 \%) \text { were suicide cases. }\end{array}$ \\
\hline
\end{tabular}


Table 5. More common assumed causes and factors in suicide.

\begin{tabular}{|c|c|c|c|c|c|}
\hline \multirow{3}{*}{ Identified possible causes } & \multicolumn{5}{|c|}{ Studies } \\
\hline & \multicolumn{2}{|c|}{ Feroz et al. 2012} & \multirow{2}{*}{ Halim et al. 2010} & \multirow{2}{*}{ Reza et al. 2013} & \multirow{2}{*}{ Ahmed et al. 2004} \\
\hline & Informed by household head & From other causes & & & \\
\hline Emotional stress due to quarrel in family & $63.0 \%$ & $57.0 \%$ & $50.7 \%$ & $65.5 \%$ & $57.0 \%$ \\
\hline Poverty & $24.3 \%$ & - & - & $18.6 \%$ & $8.6 \%$ \\
\hline Long-term illness & $8.6 \%$ & $17.0 \%$ & $8.6 \%$ & $19.5 \%$ & - \\
\hline Failure in exam & $2.9 \%$ & - & - & $5.3 \%$ & - \\
\hline Suicidal death in near relative & - & $23.0 \%$ & - & $48.7 \%$ & - \\
\hline Substance abuse & - & $5.8 \%$ & - & $5.3 \%$ & - \\
\hline Stressful events & - & - & $25.4 \%$ & - & - \\
\hline History of criminal behaviour & - & - & - & $2.6 \%$ & - \\
\hline Social deprivation & - & - & $36.6 \%$ & - & - \\
\hline Uncertainty about future & - & - & - & $15.9 \%$ & - \\
\hline Not raised by biological parents & - & - & - & $5.3 \%$ & - \\
\hline Marital disharmony & - & - & $49.3 \%$ & $46.9 \%$ & $41.7 \%$ \\
\hline Previous attempt at suicide & - & - & - & $43.3 \%$ & - \\
\hline
\end{tabular}

psychiatric illness), indicates that elderly people in Bangladesh are more prone to depression and suicidal ideation than other adults. Another rural community-based study, conducted in a large sample aged 12 to 70 years found that some 282 per 100,000 people were "at risk", having had had prior thoughts about suicide in their lifetime. The older the individual, the more years "at risk" for suicidal ideation-but this was not controlled for in this particular study.

\subsection{Completed Suicide in Community and Population-Based Studies}

Table 3 summarizes 10 studies conducted in community populations, where completed suicide was identified. Six of the studies were conducted only in rural areas, and the rest at the national level including both urban and rural areas. The study of Alam and Colleagues [49] found that the proportion of all deaths attributable to completed suicide in two rural areas was 3.5\% (in Abhoynagar district) and 1.5\% (in Mirsarai district) among all adults. In both areas, women had a higher proportion of deaths from suicide in their life-time, with proportions of $5.1 \%$ and $2.5 \%$ respectively.

A study in rural areas of North-West Bangladesh observed that in women aged 15 to $49,5.7 \%$ of total deaths were attributed to suicide [50]. A similar outcome, implying that $6.6 \%$ of all deaths were due to suicide was reported in another study which included nearly 62,000 women $(15+)$ of "reproductive age" from 70 villages in 10 rural districts [37]. This study found that women were more than twice as likely to commit suicide than men $(4.2 \%$ of all deaths in men, versus $8.9 \%$ in women). 
Higher suicide rates were also found amongst women (13 versus 8 per $100,000)$ in an earlier study of Ahmed and colleagues, which included data from 1982-98 in a rural area (Matlab) in Bangladesh. For the period 1976-86 in the same rural area (Matlab), Fauveau and Blanchet [51] observed that $4.9 \%$ of deaths among non-pregnant women at age 15 - 44 years were due to suicide, while $4.1 \%$ of post-partum deaths in the same age group were attributed to the same cause. However, suicide amongst women was highly concentrated (54\%) in the age group 15 - 19 years.

From the national level studies, we conclude that women are significantly more prone to completed suicidal behaviours than are men. The Bangladesh research indicates an inverse ranking ( $\mathrm{F}>\mathrm{M}$, unlike most other countries) in gender ratios, i.e. more suicide deaths for females than for males [29].

A national-level survey in 2003 estimated that 7.3 per 100,000 of the Bangladeshi population died by suicide, the highest rate being found among people aged 60 years or more. This research by Mashreky and colleagues [35] also indicated that the likelihood of suicide as a cause of death was 17 times higher in rural than in urban areas. Adolescents in rural areas were particularly likely to die from suicide compared with adolescents in other countries (20.1 per 100,000 population), and in this sub-population of suicides females were more likely to die by suicide (22.7 in females versus 17.7 per 100,000 in males).

A comparative analysis of two national level surveys of Bangladeshi females aged 10 to 49 by Nahar and Colleagues [41] compared data for the years 2001 and 2010, and estimated the prevalence of suicide to be 23 and 16 per 100,000 in the two years compared, which indicated a decrease in suicide in Bangladesh in the younger female population. The Health Science Bulletin of ICDDR,B stated that during 1983-2002 in two sub-districts in South-West Bangladesh, the suicide rate for all ages was 39.6 per 100,000 populations per year; amongst those less than 40 it was higher, at 42.0 per 100,000 populations [52].

\subsection{Completed Suicide Described in Hospital-Based Studies}

We found six studies on completed and attempted suicide, conducted by psychiatrists and pathologists working in hospital settings. Two studies in a tertiary-level hospital found that $94.9 \%$ and $81.6 \%$ of all poisoning related deaths were attributed to suicide [53] [54]. Another study in the same hospital investigated the cause of death of 2534 individuals within the hospital's catchment area, and estimated that $18 \%$ were attributable to suicide, mainly by poisoning [55]. That study also found that suicide victims among women increased by 8 percent per annum during 1988-97. Of the 467 suicide deaths, $45.8 \%$ involved females.

A study by Chowdhury and Colleagues [56] in a hospital of the southern region of the country found, in a review of hospital records that a surprising number-68.7\% - of total deaths had occurred due to suicidal actions. A largescale study by Hussain and Colleagues [57] of 4751 health facilities, including all of the 13 government medical college hospitals, five infectious disease hospitals, and 96 maternal and child welfare centres, found that $10.7 \%$ of all deaths were 
attributable to suicide amongst women: suicide fatalities in the age group 10 - 19 years were the most frequent (21.7\%). These researchers in reviewing medical records of deceased people aged 10 to 50 years in health facilities across Bangladesh, found that half of the injury-related deaths were due to suicide. The rate of suicides was higher in the Khulna administrative division (27.0 per 100,000) than in the other four administrative divisions of the country (range $3.5-11.3$ per 100,000) [57]. This means that a large geographic variation was observed in the South-West of Bangladesh, an area marked by shipping, port facilities, and manufacturing, rather than acute rural poverty.

\subsection{Possible Causes and Factors Underlying Suicide}

Some of the studies calculating suicide-related prevalence have investigated, explored or speculated about the causes and factors underlying suicidal behaviour (Table 5). These studies have described "emotional stress due to family quarrel" as the most common factor of aetiological significance (but these were usually post hoc speculations, without comparison with non-suicidal controls). Feroz and Colleagues [14] reported that "emotional stress due to family quarrel" was frequent (in 60\%) in the lives of people who later killed themselves. But again, how this was measured, and the lack of any non-suicidal comparison populations make this a tentative speculation concerning aetiology. Using the deceased's relatives as sources of information may elicit rationalisations from people who feel covertly guilty about the death of a family member [2].

The second most common cause claimed was poverty, according to the work of Feroz and Colleagues [14]. Three other studies found "emotional stress due to family quarrel" as the most commonly alleged cause, with relatively high frequencies (50.7\%, 65.5\% and 57\%) [13] [14] [58]. "Suicidal death in any relative" (23.0\%, 48.7\%), "marital disharmony" (49.3\%, 46.9\% and 41.7\%) and "previous attempts to suicide" (43.3\%) were also reported as prevalent causes or factors associated with suicide in several studies [13] [14] [59]. Infertility was also identified as a possible causal factor in suicide [37]. In impoverished families the role of the young wife must focus on adequate performance in providing her husband with good food, good sex, and good children. "Failure" in such role performance can have serious consequences. Divorce and expulsion from the family home by husband is one possibility'; severe physical punishment is another; voluntary or involuntary death occurs at the extreme end of this spectrum of sexist maltreatment [60].

\subsection{Methods of Suicide}

Poisoning was identified as the most common method for committing suicide among both males and females, followed by hanging. Mashreky and Colleagues found in a national survey that $78 \%$ of suicides among males and $50 \%$ among females had used this method [35]. Pesticide was the most frequently used poi-

${ }^{4} \mathrm{Qu}$ 'ranic law prescribes that if a man divorces his wife for any reason other than her adultery, he must maintain her and all of her children at the same material level that she and her children enjoyed in marriage. This Qur'anic principle is widely ignored, however. 
son (in $80 \%$ ). By hanging themselves, $19 \%$ of males and $21 \%$ of females committed suicide in Bangladesh [35].

In an urban hospital-based study in Dhaka city by Qusar and Colleagues [61], it was observed that most patients who attempted suicide used drugs (usually benzodiazepines or tricyclic antidepressants) and chemicals (kerosene, bleaching agents, organophosphorus) for attempting (and sometimes completing) suicide. Of the 44 attempted suicide cases 18 were male and 26 female; $95 \%$ of cases used drugs and chemicals. Only two males attempted suicide by hanging. (It is possible that self-poisoning in urban areas is more likely to result in resuscitation, since hospital emergency facilities are easily reached, which would not be the case in many rural areas).

A community-based study in a rural area by Feroz and Colleagues [14] observed that hanging was the most common method $(62.5 \%)$, followed by poisoning (31.2\%). Rail and road injuries (deliberately standing before trains or traffic) accounted for $6.2 \%$ of completed suicide events. However, a comparative analysis of two national surveys in 2001 and 2010 found that poisoning was the most common method (68.2\%) followed by hanging $(19.7 \%)$ in the first year of focus [41]. In 2010 poisoning, while being the most common method, was used less often (53.1\%), while hanging was increasingly common (40.6\%). Given that drowning is the commonest cause of "accidental death" in a country with many waterways and frequent flooding, it is surprising that so few officially recorded suicides have used this method. The possibility remains that numbers of such drowning deaths are actually suicide, but are not recorded as such. Or it could be as Colucci and Lester [9] observe in their cross-cultural work on suicide, that for some, suicide is a symbolically aggressive act, and slow or spectacular methods (poisoning, hanging oneself within the household) have important symbolic significance, unlike "just another drowning death".

\subsection{Socioeconomic Variation in Suicide, Suicide Attempts and Suicidal Ideation}

Some of the studies reviewed measured rates of suicidal behaviour according to socioeconomic differences. Variables identified have been educational level, socioeconomic status and income level. Feroz and Colleagues [14] found that of those who committed suicide, around one third (33.3\%) had education up to secondary level and another $28.6 \%$ up to primary level. Intermediate educational levels apparently had significantly lower rates: $45.7 \%$ of the people who committed or attempted suicide belonged to the least educated class, compared with $37.1 \%$ in the lower middle class, and the fewest (17.2\%) in the middle and upper-class (these estimates did not calculate rates according to the populations at risk in each educational or socioeconomic category).

Families with low incomes (3000 to 5000 Taka, about US\$38 to $\$ 62$ per month) had the highest rates of suicidal behaviour. Socioeconomic status, measured by a composite score of earning capacity, housing status, and possession of essential and luxury goods in the family, identified a clear socio-economic gra- 
dient in completed and attempted suicide cases: $68.4 \%$ of such cases occurred in the lower and lower-middle classes, compared with $7.3 \%$ in those belonging to the upper class. No data are available on differential methods and motives in suicide, according to social class criteria.

Reza and Colleagues [13] observed that $80.5 \%$ of all suicide and para-suicide cases were from lower (<3000 Taka i.e. $\$ 38$ per month) or lower-middle (3000 5000 Taka per month) income groups. Through a national survey in 2003, Mashreky and Colleagues observed that the majority of suicide victims (55.0\%) were found to be economically very poor with a monthly family income of less than $\$ 50$ a month; and more than $14 \%$ of the suicide victims' families earned less than $\$ 25$ a month [35]. The same study found also that literacy was a strong correlate suicidal behaviour ( $42 \%$ of the suicide victims were illiterate); less than $7 \%$ had a higher secondary education or above.

In sum, the studies reviewed suggest the strong possibility that chronic poverty associated with poorer education and illiteracy, is a significant risk factor for suicidal behaviours. Despite some methodological problems in these studies, we feel that it is safe to conclude that completed suicide rates are significantly higher in the very poorest groups, and these economic circumstances may be of aetiological significance. Nevertheless, it is also true that the large majority of the very poor in Bangladesh do not attempt or complete suicide. This is a perennial problem in suicidology: why do so few people kill themselves when the conditions of life for so many are wretched, painful and uncertain? [6]

\section{Summary and Review of Findings}

The main findings from this literature review suggest that young married women (15 - 29 years) in rural areas of Bangladesh are particularly at risk for suicidal behaviour, including suicide and suicidal attempts. Girls aged 10 to 14 (including some who were already married) also had high rates of suicidal behaviour. In contrast, in the world literature younger adolescents aged $10-14$ have been identified as having much lower rates of completed suicide than older individuals [5]. The self-killing of young Bangladeshi females occurred both prior to or soon after their being married to older men.

These adolescents also had an unexpectedly high death rate from violence that was not self-inflicted, an indicator of the very vulnerable status of these individuals whose levels of formal schooling were minimal, and who lived in impoverished families [36]. Another possibility is that some of these young women were in fact murdered, or were required by others to kill themselves, crimes passed off as suicide [62].

Such young women often had experience of physical and sexual violence imposed by their family, and then by their spouse. One study found that following marriage, adolescents were physically abused by both their original families, and their new husband, so that levels of abuse actually increased [37].

Poisoning was identified as the most frequent method for committing and attempting suicide, followed by hanging. Poisoning using pest control mixtures in 
the absence of medical help, is likely to be a slow and painful method of selfkilling, and the possibility that this was an involuntary form of death cannot be discounted. Alternative methods of suicide, such as purposive drowning, or road and rail injuries could be rapidly fatal, but were atypically used [14].

It was suggested by some studies that lower socioeconomic status in terms of income, education or assets, were significant antecedents of suicidal behaviour [13] [14] [35]. One study when comparing suicide cases between two surveys in 2001 and 2010, found a decrease in such incidences. However, further studies are required to arrive at definitive conclusions about social factors in the aetiology of suicidal behaviours [41].

It is clear from the research that most cases of completed suicide occurred in rural areas, and unlike studies undertaken in developed countries, females outnumbered males in completed suicide. These young women were poorly educated or illiterate, lived in families enduring extreme and chronic poverty, in which the status of females was low, and violence against women was common.

The evidence suggests that married women aged 15 - 29 years with experience of physical and sexual violence, living in rural areas constituted the most vulnerable segment for suicidal behaviour, although we note one study which has pointed to high dispositions to suicide in the very old [12]. We observed some variation between studies in relation to methodologies employed. Most studies used cross-sectional surveys (11 out of 23 studies), but lacked information on control or comparison groups who had not completed suicide. Without such information, studies are confined to post hoc generalisations, which may reflect localised "social meanings" of suicide, according to Colucci \& Lester [9], rather than more systematic estimates of antecedents of suicidal behaviour. Emotional stress due to quarrel in the family, marital disharmony, and suicide in any relative were often cited as predisposing factors in suicidal behaviours, but these could be post hoc justifications (Table 5). There are no carefully controlled designs in the literature on Bangladesh which can pinpoint exact causes. But there is enough information on high rates of suicide in young, rural women living in impoverished families to give us confidence in elaborating programmes of public health intervention.

In future research we should like to see closer attention given to the validity and reliability of judgements about whether suicide has occurred. Further studies should employ the methods standardised in epidemiological research, with better calculations of risk status for different age and class groups. More work needs to be done on the social epidemiology of risk factors, as well as the drawing out of public health models for intervention with potentially suicidal populations at early stages of rise, and the initiation of demonstration projects and studies with control or contrast groups.

We note with interest the work of Ronsmans and Khlat [62], which was not included in the studies in the above matrix of studies on suicide, since they conflated "unintentional deaths" in women aged 15 to 49 into a single rate, including deaths from suicide, murder, and failed abortions. They argue that these 
three kinds of death (particularly common in teenagers) are linked within a poverty-afflicted rural culture, in which unwanted females and unwanted children and/or pregnancies are sometimes subjected to extreme violence, including forced abortions (in the case of a rape victim), forced suicides, or becoming a victim of murder. There is a need here for qualitative and ethnographic studies on the social meanings of "suicide", and other forms of death, and of the empowerment of women.

Hospital-based studies have provided important complementary information to that provided by the large-scale community studies, probably using better information sources, and more standardised methodologies. While the community-based studies have identified suicide cases using "verbal autopsy", hospital-based researchers may have given more accurate accounts of events leading to suicidal death. In the community-based studies, data for verbal autopsies screening very large populations, were primarily collected by research assistants with moderate-educational levels, and minimal knowledge of health research [49]. In contrast, in hospital-based studies, medical records were reviewed and psychological autopsies were conducted by medically trained staff [56] [58].

The review data indicate that in Asia, suicide rates are higher in the South Asian region than elsewhere in the world [30], although Bangladesh has lower suicide prevalence than some other countries in the region. In India, suicide rates vary between 8.1 and 58 per 100,000 across states [31]. The rate found in Sri Lanka at 37 per 100,000 population [32] [33] is the highest recorded. Nepal experienced a rate of 24.9 per 100,000 populations, with the rate for men and women being 30.1 and 20.0 per 100,000 respectively ${ }^{5}$. In Nepal, unmarried women aged 10 - 24 years were at the highest risk of suicide [34]. In Bangladesh suicide rates in women were found to be somewhat lower (but still high by international comparisons) ranging from 7.9 to 23.0 per 100,000 population within the age and gender groups studied [35] [41].

Compared to many other world countries, Bangladesh experiences a considerable difference in the prevalence of gender-related suicide, with the unusual manifestation suicide prevalence being higher in females [35]. Young married women contribute disproportionally, and these rates of self-harm and self-killing appear to reflect physical and sexual violence imposed by both family and spouse [14] [37] [62] [63]. Sometimes this abuse is extended to effectively "selling" a young girl into bondage, which may result in brothel servitude, or sexual trafficking to another country [26]. There may be cases of "hidden suicide" within these brothels.

\section{Development of a Public Health Prevention Model}

First of all, the low status of female children, adolescents and young women in rural Bangladesh (and in the slum dwellings on the periphery of cities into which many of the rural poor migrate) compared with that of males cannot be overstated. The case for an Islamic feminism in Bangladesh has been eloquently ar- 
gued by Hashmi (2000) in Women and Islam in Bangladesh: Beyond Subjection and Tyranny [23]. Hashmi begins with a quote from The Qur'an: "And for women are rights over men similar to those of men over women.” (2:228) — that is, Islam properly observed, guarantees women equality with men, except under Qu'ranically prescribed instances: a woman for instance will inherit a smaller amount of a family's property. The same Qur'anic verse establishes the duties of men with regard to their spouses.

But in rural Bangladesh a woman will likely inherit nothing despite her Shariah law entitlement, all property being claimed by those in the male line, whenever there is wealth or property to leave. Hashmi ends his study of Bangladeshi women with the gloomy conclusion: “... patriarchy has been the main stumbling-block towards the empowerment of Bangladeshi women. The marriage of convenience between patriarchy and popular Islam has aggravated the situation." (p. 209).

In the rural-urban slums described in the ethnographic accounts of Das [25] and Hossain [26], there is profound poverty, and the absence of schools, mosques or madrassas (religious schools) [25] [26]. Unremitting malnutrition, lack of medical care, and starvation-level employment means that "unwanted" females (including girls as young as 12) may be sold either for sex-trafficking, or for use in one of the many brothels which exist in every city of Bangladesh [27].

We propose a model for preventing suicidal which, first of all, reflects existing epidemiological data and the identified risk factors from the literature review. It is clear that any programme must be focussed firstly on girls and women, and their rights in an Islamic society. This also means the initiation of programmes of education for both adolescent females and males 6 . In elaborating this approach, we propose a demonstration project in a rural area of Bangladesh, which will be contrasted with a "control" district of similar demographic and socioeconomic status.

A quasi-experimental, school-focused approach in both the focus and control districts, with systematic measures over a three-year period proved to be highly cost-effective in an English setting, reducing indicators of poor mental health and delinquency [65] [66]. We can see no reasons why this model could not be applied in rural Bangladesh.

The hypothesis in applying this evaluative framework in Bangladesh would be that the adolescents graduating from the focus area high school(s), would over five years manifest a significant reduction in suicidal ideas, gestures, and suicide attempts, compared with students graduating (or failing to graduate) from secondary school in the contrast or control district, and would be more equipped to negotiate or avoid the subordinated roles which involve severe physical punishments, and a grossly inferior status. The central focus will be on a secondary

${ }^{6}$ Such educational programmes must, we argue, include a proper Islamic education which both restrains individuals from self-killing, and also requires individuals to fulfil the ethical obligations of Islam which oblige individuals to treat women with respect, in accordance with Qur'anic principles [24] [64]. 
school in which females and males will be encouraged to attend, with the aid of financial bursaries which would pay the fees and other costs of secondary schooling (academic, technical, or religious), offering an allowance of about $\$ 20$ per month to the family of each student enrolled. This proposal is based on a successful model deployed in The Philippines [67].

Ideally we would like to offer a "basic citizen's income" offered to adults and children of the type pioneered in a rural area of Madhya Pradesh, India by Davala and Colleagues [68] for all families whose children are enrolled in the experimental programme. If applied in Bangladesh such a programme would guarantee an income of US $\$ 50$ per month, for a family (typically, four adults, including parents and other adults, and four children). While by "developed" world standards this sum seems small, nevertheless within the context of Bangladesh this income supplement would, on this Indian evidence, be sufficient if allocated on a per capita basis (and not simply to the head of household) enable both boys and girls to stay in school and complete their education, to postpone early marriage, to seek appropriate health care when needed, and to be wellnourished (an important prerequisite for school achievement). Within the focus school adolescents would receive an appropriate Islamic education on the rights and duties of individuals, including the proper treatment of girls and women. We acknowledge however, that major resources are required to initiate a "citizen's income" programme of this type, which is beyond that scope of the present researchers.

A modified approach which we used in The Philippines [67], giving financial support for secondary school students to a parent (conditional upon the student continuing to attend secondary education) would however mean that the pressures for adolescents to forgo education because their employment or marriage was necessary to support an impoverished family, would no longer prevail. Three of the authors of this paper are Muslims, and feel that the students in the focus secondary institutions should receive an adequate education in Muslim citizenship, the universal values of Islam as outlined in the educational models we have researched [66], in which students absorb the high ideals of daily living prescribed by the Qur'an and the Sunnah.

Students in the focus school(s) would complete measures of mental health, values and social adjustment at the beginning of the five-year programme, and at various intermediate points. In the contrast district we will not attempt to recruit individual controls (since that would impose on us the ethical obligation of helping those students as well). Rather, we will replicate the methods of Ahmed and colleagues [37] in asking the contrast group community sample about incidents of self-harm, and family deaths in the previous two years, with data collection at the beginning and again at the end of the five-year experimental programme [37]. Since the experimental programme would be delivered in collaboration with a leading NGO in Bangladesh (ICDDR-B), we propose to locate the focus secondary institutions (academic, technical, and religious) in Matlab District, in which region ICDDR-B runs a district hospital. 


\section{Case Studies of Suicide in Bangladesh, and the Manner in Which They Were Reported in a Single Day, by the Local and National Press}

The daily press in Bangladesh frequently carry reports of "suicide", often in a sensationalist or flamboyant manner, naming the victim and often carrying photographs of the deceased. There is a danger here of an "imitative effect" [69], in which widely publicised acts of suicide (in both public and electronic media) may trigger attempts by those already at risk. In addition, knowing that one's flamboyantly displayed suicide may humiliate or expose the family or spouse of the deceased person, could be a factor in suicidal motivation [9]. Concerning Case six, a 15-year old girl who killed herself when facing the prospect of being married, it is relevant to note the research of Islam and colleagues [70], which shows that more than two thirds of marriages in rural Bangladesh have involved a girl aged between 12 and 17. These "child marriages" are associated to a statistically significant degree with maternal and child mortality, compared with the reproductive status of mature women. Correlates of child marriage (in which the child has no control of her status, or choice of partner) are poverty and lack of education, and on marriage all hope of completing secondary education is ended.

Case one: An aspiring young model from Chittagong committed suicide allegedly over marital disputes.

$\mathrm{M}, 25$, was found hanging from the ceiling by her scarf in her Chittagong home. She came from a Hindu family. Her father is a barber by profession. He has accused seven people, including Mithila's husband $U$ and his mother, for driving his daughter into taking her life. Police had found M's mobile phone and a handwritten note lying near her body. "The note said: "I married out of love. He [husband] stopped loving me after marriage." M's father said the couple had been in a relationship for seven years before marrying last November (2016). He said U's family kept him away from seeing his daughter after the marriage... Two of M's Facebook posts prior to her death indicated that she was in a fragile, emotional state.

In a "status" posted on January 30 at 11:49 pm, she wrote that she was going to take her life on January 31, and clarified that her decision was not influenced by anyone. Translated, the Bangla message reads: "I will commit suicide tomorrow. Nobody has dumped me, nor did I dump anyone. But I will kill myself." On January 31 at 7:28 pm, she wrote on Facebook she was gradually nearing her end.

Case two: Father, daughter "commit suicide for justice"

Depressed about not getting justice, a man with his eight-year-old daughter were involved in a case of murder-suicide by jumping before a train. The bodies of H. A. 45, a farmer, and his adopted daughter A, were found near the rail tracks at Sreepur Railway Station. The man claimed that their only child A was sexually abused by a neighbour some three months before. $\mathrm{H}$ (the wife) reported the matter to a regionally-elected politician, who did not take any steps, which depressed her husband.

Case three: Maldivian medical student and model, $R$ committed suicide by hanging 
$\mathrm{R}$, a second-year student, was found dead in her room at the women's dormitory of the college... Prof Mansur Rahman of Barind Medical College, chief of the three-member medical board that performed an autopsy on her body on Friday, said they did not find any strangulation marks on her neck. There were no injury marks on her body either. "All members of the board are of the view that it is a clear case of suicide," he said. Her family members, however, rejected the report and were considering seeking a second autopsy. R's family members had no confidence in the report and they are considering seeking a second autopsy by an independent authority. "We've seen her body, her tightly-held fists, wide strangulation marks on the neck and multiple bruises as if somebody strangled her. We are not ready to believe it was a suicide," said R's mother.

Case four. Couple commit suicide in Tangail

A couple committed suicide in Tangail. R, 24 and S, 20 married about four months ago after a love affair and there was no dispute in their conjugal life according to neighbours. Family members found their room locked from the inside, till Monday noon. They entered the room after breaking the door and found them hanging from the ceiling. $S$ had been seeking money from her parents since the marriage for her husband $\mathrm{R}$, a driver by profession, to start a business, but her parents refused, according to neighbours. The actual reason behind the suicide of the couple could not be known immediately.

Case five: Two students reportedly committed suicide in Chittagong and Shariatpur as they did not secure expected results in the Secondary School Certificate (SSC) examinations this year.

In Chittagong, body of $\mathrm{M}$... was found hanging from the ceiling at their house. $M$ took part in SSC examinations and obtained GPA 3.77 (out of 5.00) from the science group. He committed suicide around 5:30 pm when his mother was out of the house. Another student, S, 16, committed suicide by taking poison at his home. He entered for SCC exams but failed to achieve his expected result.

Case six: Child marriage claims another life

A teenage girl committed suicide by hanging herself from the ceiling in her living room. Fifteen-year-old $M$ killed herself finding no other way out of being married off by her family. The newspaper carried a high school photograph of M, who was pulled from school in order to marry a much older man, who offered her parents a substantial dowry payment. The newspaper report (Daily Star, April 19, 2017), in reproducing this photograph of a hopeful adolescent looking towards a bright future, dramatically demonstrates the devastation of an arranged marriage in destroying her hopes for the future, and we reproduce her picture here for the same reasons.

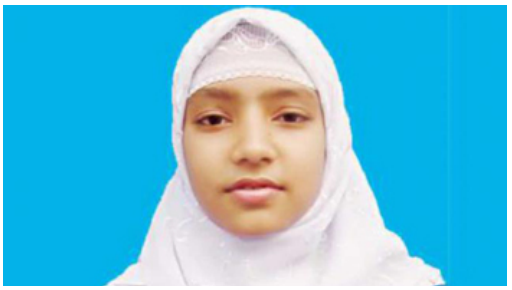




\section{Suicide Prevention in Bangladesh: National Initiatives}

“Take your religion from this red-haired one." Prophet Muhammad, speaking of his beloved wife Aisha [71]

Our proposed national model, which would run in parallel to the experimental programme outlined above, reflects programmes of suicide prevention which have been offered and evaluated in other cultures [7] [11] and includes both general and specific interventions (e.g. counselling and mental health support following a suicide attempt).

The epidemiological data from the above review suggest that married women and adolescents aged 12 to 29 years who experience physical and sexual violence from husband, and from their family in rural areas are significantly at risk for suicide, suicide attempts and suicidal thoughts. Awareness building should be considered as an important approach, concerned with how women of all ages recognise and resist the male hegemony which imposes violence (and suicidal despair) on women [72]. This can also be approached through educational programmes in secondary schools, not only in the schools involved in the proposed experimental study. But the reality is that free basic schooling is available only at the primary level. Many parents cannot afford to keep a child in secondary schooling, and household duties, marriage, and basic-level employment are the fate of many young adolescents.

For those who have already left education, telephone help-lines are an interesting possibility, given the ubiquity of mobile phones, even in very poor families in rural areas. A national helpline has been established in Bangladesh for communication to an online support service for those who are enduring stress, despair, and suicidal thoughts-but this new initiative is not well-publicised, or well-funded, and the professional quality of the help offered is unknown. Such helplines are well established in many countries, and are well-researched [10]. This telephone helpline could be publicised through TV advertisements, given that most individuals in rural areas are able to watch TV programmes, albeit in a communal space. TV is another possibility of giving the message (in brief information programmes) of the righteousness of treating girls and women with the respect they deserve in a truly Islamic culture. The Hadith of the Prophet $\mathrm{Mu}-$ hammad (such as those related by his wife Aisha) on the care of, and respect for a wife should be more widely known [71].

National programmes of health surveillance should regularly monitor both the physical and mental health of the nation, including the neglected issue of depression and suicidal ideas in the elderly [12].

In sum, on the basis of the knowledge derived from this literature review, our knowledge of Bangladeshi culture, and our commitment to the highest ideals of Islam, we suggest that more research in both urban and rural areas should be conducted, which can form the basis for monitoring new prevention programmes aimed at reducing suicidal behavior in Bangladesh, and for raising the status of women to that promised by Islam. Bangladesh's Hindu minority (some ten per cent of citizens) also deserve culturally appropriate models for suicide 
prevention, an issue that must be explored in further research.

\section{Authorship}

All four authors had equal responsibilities in designing, carrying out, writing and commenting on this review paper.

\section{Funding}

This research received no external funding.

\section{Ethical Approval}

The authors considered that no ethical approval was needed in writing a review paper, which had no direct contact with human subjects.

\section{References}

[1] Kreitman, N., Philip, A., Greer, S. and Bagley, C. (1969) Parasuicide. British Journal of Psychiatry, 115, 746-747. https://doi.org/10.1192/bjp.115.523.746-a

[2] Kreitman, N. (1977) Parasuicide. Wiley, Chichester.

[3] Tse, J.W.-L. and Bagley, C. (2002) Suicide and Death Education in Chinese Adolescents: Hong Kong Studies. Ashgate, Aldershot.

[4] Hawton, K. and O'Connor, R. (2012) Suicide: Major Themes in Health and Welfare. Routledge, London.

[5] Hawton, K. (2005) Prevention and Treatment of Suicidal Behaviour: From Science to Practice. Oxford University Press, London.

[6] Shrivastava, A., Kimbrell, M. and Lester, D. (2012) Suicide from a Global Perspective: Public Health Approaches. Nova Science Publishers, New York.

[7] Hawton, K., Witt, K.G., Salisbury, T.L., Arensman, E., Gunnell, D., Hazell, P., Townsend, E. and van Heeringen, K. (2016) Psychosocial Interventions Following SelfHarm in Adults: A Systematic Review and Meta-Analysis. The Lancet Psychiatry, 3, 740-750.

[8] Gjelsvik, B., Heyerdahl, F., Holmes, J., Lunn, D. and Hawton, K. (2017) Looking Back on Self-Poisoning: The Relationship between Depressed Mood and Reporting of Suicidal Intent in People Who Deliberately Self-Poison. Suicide and LifeThreatening Behavior, 47, 228-241. https://doi.org/10.1111/sltb.12278

[9] Colucci, E. and Lester, D. (2012) Suicide and Culture: Understanding the Context. Mass Hogrefe Publishing, Cambridge.

[10] Lester, D. and Rogers, I. (2013) Suicide: A Global Issue. Praeger, New York.

[11] Zalsman, G., Hawton, K., Wasserman, D., van Heeringen, K., Arensman, E., Sarchiapone, M., Carli, V., Höschl, C., Barzilay, R., Balazs, J. and Purebl, G. (2016) Suicide Prevention Strategies Revisited: 10-Year Systematic Review. The Lancet Psychiatry, 3, 646-659.

[12] Wahlin, Å., Palmer, K., Sternäng, O., Hamadani, J.D. and Kabir, Z.N. (2015) Prevalence of Depressive Symptoms and Suicidal Thoughts among Elderly Persons in Rural Bangladesh. International Psychogeriatrics, 27, 1999-2008. https://doi.org/10.1017/S104161021500109X

[13] Reza, A.S., Feroz, A.H., Islam, S.N., Karim, M.N., Rabbani, M.G., Alam, M.S., Rahman, M.M., Rahman, M.R., Ahmed, H.U., Bhowmik, A.D. and Khan, M.Z. (2014) Risk Factors of Suicide and Para Suicide in Rural Bangladesh. Journal of Medicine, 
14, 123-129. https://doi.org/10.3329/jom.v14i2.19653

[14] Feroz, A.H., Islam, S.N., Reza, S., Rahman, A.M., Sen, J., Mowla, M. and Rahman, M.R. (2012) A Community Survey on the Prevalence of Suicidal Attempts and Deaths in a Selected Rural area of Bangladesh. Journal of Medicine, 13, 3-9. https://doi.org/10.3329/jom.v13i1.10042

[15] Ganatra, B.R., Coyaji, K.J. and Rao, V.N. (1998) Too Far, Too Little, Too Late: A Community-Based Case-Control Study of Maternal Mortality in Rural West Maharashtra, India. Bulletin of the World Health Organization, 76, 591.

[16] Inskip, H.M., Harris, E.C. and Barraclough, B. (1998) Lifetime Risk of Suicide for Affective Disorder, Alcoholism and Schizophrenia. The British Journal of Psychiatry, 172, 35-37. https://doi.org/10.1192/bjp.172.1.35

[17] Bagley, C., Wood, M. and Khumar, H. (2009) Suicide and Careless Death in Young Males: Ecological Study of an Aboriginal Population in Canada. Canadian Journal of Community Mental Health, 9, 127-142. https://doi.org/10.7870/cjcmh-1990-0009

[18] WHO Preventing Suicide (2014) A Global Imperative. World Health Organization, Geneva.

[19] Bangladesh Bureau of Statistics (2008) BBS Monthly Statistical Bulletin, Bangladesh, July to December 2007. Dhaka.

[20] Matin, K. (2014) Income Inequality in Bangladesh. Proceedings of Rethinking Political Economy of Development Conference, Dhaka.

[21] Huda, T.M., Hayes, A., El Arifeen, S. and Dibley, M.J. (2017) Social Determinants of Inequalities in Child under Nutrition in Bangladesh: A Decomposition Analysis. Maternal \& Child Nutrition. https://doi.org/10.1111/mcn.12440

[22] Chowdhury, F.D. (2016) Islam and Women's Income: Dowry and Law in Bangladesh. Routledge, London.

[23] Hashmi, T. (2000) Women and Islam in Bangladesh: Beyond Subjugation and Tyranny. Palgrave MacMillan, Basingstoke.

[24] Khan, M.W. (1998) Principles of Islam. Goodword Books, Birmingham.

[25] Hossain, S. (2010) Urban Poverty in Bangladesh: Slum Communities, Migration and Social Integration. IB Tauris, London.

[26] Das, T.K. (2000) Social Structure and Cultural Practices in the Slums of Rural Dhaka, Bangladesh. Northern Book Centre, New Delhi.

[27] Bagley, C., Kadri, S., Shahnaz, A., Simkhada, P. and King, K. (2017) Commercialised Sexual Exploitation of Children, Adolescents and Women: Health and Social Structure in Bangladesh. Advances in Applied Sociology, 7, 137. https://doi.org/10.4236/aasoci.2017.74008

[28] Chen, Y.Y., Chien, C., Wu, K., Yousuf, S. and Yip, P.S. (2012) Suicide in Asia: Opportunities and Challenges. Epidemiological Reviews, 34, 129-144. https://doi.org/10.1093/epirev/mxr025

[29] Beautrais, A.L. (2006) Suicide in Asia. Crisis, 27, 55-57. https://doi.org/10.1027/0227-5910.27.2.55

[30] Jordans, M.J., Kaufman, A., Brenman, N.F., Adhikari, R.P., Luitel, N.P., Tol, W.A. and Komproe, I. (2014) Suicide in South Asia: A Scoping Review. BMC Psychiatry, 14, 358. https://doi.org/10.1186/s12888-014-0358-9

[31] Joseph, A., Abraham, S., Muliyil, J.P., George, K., Prasad, J., Minz, S., Abraham, V.J. and Jacob, K.S. (2003) Evaluation of Suicide Rates in Rural India Using Verbal Autopsies, 1994-9. British Medical Journal, 326, 1121-1122.

https://doi.org/10.1136/bmj.326.7399.1121 
[32] Krug, E.G., Dahlberg, L.L., Mercy, J.A., Zwi, A.B. and Lozano, R. (2000) The World Health Report 2000: Reducing Risks, Promoting Healthy Life. World Health Organization, Geneva.

[33] Khan, M.M. and Reza, H. (2000) The Pattern of Suicide in Pakistan. Crisis, 21, 3135. https://doi.org/10.1027//0227-5910.21.1.31

[34] Simkhada, P., Van Teijlingen, E., Winter, R.C., Fanning, C., Dhungel, A. and Marahatta, S.B. (2015) Why Are So Many Nepali Women Killing Themselves? A Review of Key Issues. Journal of Manmohan Memorial Institute of Health Sciences, 1, 43-49. https://doi.org/10.3126/jmmihs.v1i4.12001

[35] Mashreky, S.R., Rahman, F. and Rahman, A. (2013) Suicide Kills More than 10,000 People Every Year in Bangladesh. Archives of Suicide Research, 17, 387-396. https://doi.org/10.1080/13811118.2013.801809

[36] Värnik, P. (2012) Suicide in the World. International Journal of Environmental Research and Public Health, 9, 760-771. https://doi.org/10.3390/ijerph9030760

[37] Ahmed, M.K., van Ginneken, J., Razzaque, A. and Alam, N. (2004) Violent Deaths among Women of Reproductive Age in Rural Bangladesh. Social Science \& Medicine, 59, 311-319.

[38] Canetto, S.S. (2015) Suicidal Behaviors among Muslim Women. Crisis, 36, 447-458. https://doi.org/10.1027/0227-5910/a000347

[39] Vijayakamur, L., Pirkis, J. and Whiteford, H. (2015) Suicide in Developing Countries: Prevention Efforts. Crisis, 26, 120-124.

https://doi.org/10.1027/0227-5910.26.3.120

[40] World Health Organisation (2007) WHO-AIMS Report on Mental Health System in Bangladesh. WHO and Ministry of Health \& Family Welfare, Geneva.

[41] Nahar, Q., El Arifeen, S., Jamil, K. and Streatfield, P.K. (2015) Causes of Adult Female Deaths in Bangladesh: Findings from Two National Surveys. BMC Public Health, 15, 911. https://doi.org/10.1186/s12889-015-2256-6

[42] Anderson, S., Allen, P., Peckham, S. and Goodwin, N. (2008) Asking the Right Questions: Scoping Studies in the Commissioning of Research on the Organisation and Delivery of Health Services. Health Research Policy and Systems, 6, 7. https://doi.org/10.1186/1478-4505-6-7

[43] Bagley, C. (2008) Mental Illness in Asian Minorities in Britain. In: Al-Refai, N. and Bagley, C., Eds., Citizenship Education in Britain: A Muslim Perspective, Brill-Sense Educational Books, Leiden, 150-170.

[44] Von Elm, E., Altman, D.G., Egger, M., Pocock, S.J., Gøtzsche, P.C. and Vandenbroucke, J.P. (2008) The Strengthening the Reporting of Observational Studies in Epidemiology [STROBE] Statement: Guidelines for Reporting Observational Studies. Gaceta Sanitaria, 22, 144-150. https://doi.org/10.1157/13119325

[45] Ellsberg, M., Jansen, H.A., Heise, L., Watts, C.H. and Garcia-Moreno, C. (2008) Intimate Partner Violence and Women's Physical and Mental Health in the WHO Multi-Country Study on Women's Health and Domestic Violence: An Observational Study. The Lancet, 371, 1165-1172.

[46] Gausia, K., Fisher, C., Ali, M. and Oosthuizen, J. (2009) Antenatal Depression and Suicidal Ideation among Rural Bangladeshi Women: A Community-Based Study. Archives of Women's Mental Health, 12, 351-358. https://doi.org/10.1007/s00737-009-0080-7

[47] Naved, R.T. and Akhtar, N. (2008) Spousal Violence against Women and Suicidal Ideation in Bangladesh. Women's Health Issues, 18, 442-452.

[48] Santos, I.S., Matijasevich, A., Tavares, B.F., da Cruz Lima, A.C., Riegel, R.E. and 
Lopes, B.C. (2007) Comparing Validity of Edinburgh Scale and SRQ20 in Screening for Post-Partum Depression. Clinical Practice and Epidemiology in Mental Health, 3, 18. https://doi.org/10.1186/1745-0179-3-18

[49] Alam, N., Chowdhury, H.R., Das, S.C., Ashraf, A. and Streatfield, P.K. (2014) Causes of Death in Two Rural Demographic Surveillance Sites in Bangladesh, 2004-2010: Automated Coding of Verbal Autopsies Using Inter VA-4. Global Health Action, 7, 2551. https://doi.org/10.3402/gha.v7.25511

[50] Labrique, A.B., Sikder, S.S., Wu, L., Rashid, M., Ali, H., Ullah, B., Shamim, A.A., Mehra, S., Klemm, R., Banu, H. and West, K.P. (2013) Beyond Pregnancy-The Neglected Burden of Mortality in Young Women of Reproductive Age in Bangladesh: A Prospective Cohort Study. BJOG: An International Journal of Obstetrics \& Gynaecology, 120, 1085-1089. https://doi.org/10.1111/1471-0528.12245

[51] Fauveau, V. and Blanchet, T. (1989) Deaths from Injuries and Induced Abortion among Rural Bangladeshi Women. Social Science \& Medicine, 29, 1121-1127.

[52] Icddr, B. (2003) Mortality Due to Suicide in Rural Bangladesh. Health and Science Bulletin, 1, 7-10.

[53] Quader, M., Rahman, M.H., Kamal, M., Ahmed, A.U. and Saha, S.K. (2010) Post Mortem Outcome of Organophosphorus Compound Poisoning Cases at Mymensingh Medical College. Mymensingh Medical Journal, 19, 170-172.

[54] Khan, N.A., Rahman, A., Sumon, S.M., Haque, M.F., Hasan, I., Sutradhar, S.R., Barman, T.K., Rahman, S., Ferdous, J., Miah, A.H. and Alam, M.K. (2013) Pattern of Poisoning in a Tertiary Level Hospital. Mymensingh Medical Journal, 22, 241 247.

[55] Islam, M.N. and Islam, M.N. (2003) Pattern of Unnatural Death in a City Mortuary: A 10-Year Retrospective Study. Legal Medicine, 5, S354-S356.

[56] Chowdhury, F.R., Rahman, A.U., Mohammed, F.R., Chowdhury, A., Ahasan, H.A. and Bakar, M.A. (2011) Acute Poisoning in Southern Part of Bangladesh-The Case Load Is Decreasing. Bangladesh Medical Research Council Bulletin, 37, 61-65. https://doi.org/10.3329/bmrcb.v37i2.8436

[57] Hussain, Y.R., Akhter, H.H., Rahman, M.H. and Rochat, R.W. (2000) Injury-Related Deaths among Women Aged 10-50 Years in Bangladesh, 1996-97. The Lancet, 355, 1220-1224.

[58] Hussain, Y.R., Akhter, H.H., Chowdhury, M.E. and Rochat, R.W. (2007) Causes of Death among Women Aged 10-50 Years in Bangladesh, 1996-1997. Journal of Health, Population and Nutrition, 25, 302-311.

[59] Halim, K.S., Khondker, L., Wahab, M.A., Nargis, F. and Khan, S.I. (2010) Various Factors of Attempted Suicide in a Selected Area of Naogaon District. Mymensingh Medical Journal, 19, 244-249.

[60] Rashid, S.F. (2006) Small Powers, Little Choice: Contextualising Reproductive and Sexual Rights in Slums in Bangladesh. Institute of Development Studies Bulletin, 37, 69-76. https://doi.org/10.1111/j.1759-5436.2006.tb00305.x

[61] Qusar, M.S., Morshed, N.M., Kader, M.A., Azad, M.A., Uddin, M.A. and Shaikh, M.A. (2010) Psychiatric Morbidity of Suicide Attempt Patients Requiring ICU Intervention. Journal of Medicine, 11, 7-11. https://doi.org/10.3329/jom.v11i1.4260

[62] Ronsmans, C. and Khlat, M. (1999) Adolescence and Risk of Violent Death during Pregnancy in Matlab, Bangladesh. The Lancet, 354, 1448.

[63] Hadi, A. (2005) Risk Factors of Violent Death in Rural Bangladesh, 1990-1999. Death Studies, 29, 559-572. https://doi.org/10.1080/07481180590962695

[64] Al-Refai, N. and Bagley, C. (2008) Citizenship Education: The British Muslim Per- 
spective. Brill-Sense Educational Publishers, Leiden.

[65] Bagley, C. and Pritchard, C. (1998) The Reduction of Problem Behaviours and School Exclusion in At-Risk Youth: An Experimental Study of School Social Work with Cost-Benefit Analyses. Child and Family Social Work, 3, 219-226. https://doi.org/10.1046/j.1365-2206.1998.00101.x

[66] Bagley, C. and Pritchard, C. (1998) The Billion Dollar Costs of Troubled Youth: Prospects for Cost-Effective Prevention and Treatment. International Journal of Adolescence and Youth, 7, 211-225. https://doi.org/10.1080/02673843.1998.9747825

[67] Bagley, C., Madrid, S., Simkhada, P., King, K. and Young, L. (2017) Adolescent Girls Offered Alternatives to Commercial Sexual Exploitation: A Case Study from the Philippines. Dignity: A Journal on Sexual Exploitation and Violence, 2.

[68] Davala, S., Jhabvala, R., Standing, G. and Mehta, S.K. (2015) Basic Income: A Transformative Policy for India. Bloomsbury Publishing, London.

[69] Robinson, J., Cox, G., Bailey, E., Hetrick, S., Rodrigues, M., Fisher, S. and Herrman, H. (2015) Social Media and Suicide Prevention: A Systematic Review. Early Intervention Psychiatry, 10, 103-121. https://doi.org/10.1111/eip.12229

[70] Islam, M.K., Haque, M.R. and Hossain, M.B. (2016) Regional Variations in Child Marriage in Bangladesh. Journal of Biosocial Science, 48, 694-708. https://doi.org/10.1017/S0021932016000110

[71] Eaton, C.L. (2008) The Book of Hadith: Sayings of the Prophet Muhammad from the Mishkat Al Masabih. The Book Foundation, Bristol.

[72] Parveen, S. (2007) Gender Awareness of Rural Women in Bangladesh. Journal of International Women's Studies, 9, 253-269.

\section{Submit or recommend next manuscript to SCIRP and we will provide best service for you:}

Accepting pre-submission inquiries through Email, Facebook, LinkedIn, Twitter, etc. A wide selection of journals (inclusive of 9 subjects, more than 200 journals)

Providing 24-hour high-quality service

User-friendly online submission system

Fair and swift peer-review system

Efficient typesetting and proofreading procedure

Display of the result of downloads and visits, as well as the number of cited articles

Maximum dissemination of your research work

Submit your manuscript at: http://papersubmission.scirp.org/

Or contact jss@scirp.org 